\title{
DEBIUTY
}

EWA OLESZCZAK

Forum Pedagogiczne

Fundacja Pomocy Młodzieży

$2015 / 2$

i Dzieciom Niepetnosprawnym „Hej, Koniku!”

Warszawa

\section{AKTYWIZACJA ZAWODOWA OSÓB NIEPEŁNOSPRAWNYCH W MODELU ZATRUDNIENIA WSPOMAGANEGO}

\begin{abstract}
Streszczenie: Osoby niepełnosprawne tworzą obecnie w Polsce dość dużą grupę społeczną. Jednym z jej głównych problemów jest zatrudnienie. Oczywiście nie można zastosować tej idei wobec wszystkich osób niepełnosprawnych, jednakże propozycja elastycznego, a zarazem bezpiecznego rynku pracy może znaleźć wśród nich liczną rzeszę zwolenników. Podjęcie tego tematu jest istotne, gdyż dotychczasowe warunki ekonomiczne osób niepełnosprawnych świadczą o ubóstwie, co niewątpliwie wpływa na nie negatywnie. Efektem takiego stanu rzeczy jest konieczność szukania nowych rozwiązań. Aktywizacja zawodowa niepełnosprawnych poprzez model zatrudnienia wspomaganego jest skuteczna dla licznej grupy takich osób.
\end{abstract}

Słowa kluczowe: niepełnosprawność, zatrudnienie wspomagane, trener pracy, otwarty rynek pracy

\section{Osoby niepełnosprawne na otwartym rynku pracy}

Na otwartym rynku pracy osoby niepełnosprawne stanowią ciągle grupę społeczną, której potencjał nie jest w pełni wykorzystywany. W wielu przypadkach nawet nie jest ujawniony czy rozpowszechniony na tyle, aby ewentualny pracodawca wiedział, na co stać osobę niepełnosprawną, jaką pracę może ona wykonywać oraz jakie warunki jej stworzyć, by praca ta była w pełni wydajna. Innym problemem jest opór pracodawców przed zatrudnianiem niepełnosprawnych. W celu uaktywnienia dużej ich grupy wszystkie strony tego procesu wymagają niezwłocznych przemian. Prawa osób niepełnosprawnych gwarantowane są przede wszystkim w Ustawie z dnia 26 czerwca 1974 roku Kodeks pracy, która ma podstawowe znaczenie dla regulacji stosunków pracy. Innym aktem prawnym, który od dawna już reguluje kwestie związane z zatrudnieniem osób niepełnosprawnych, jest Ustawa $z$ dnia 27 sierpnia 1997 roku o rehabilitacji zawodowej i społecznej oraz zatrudnianiu 
osób niepełnosprawnych (Dz.U. nr 123, poz. 776). Zawiera ona przepisy związane z kwestiami finansowymi dotyczącymi zatrudniania niepełnosprawnych oraz wiele innych uszczegółowień. Duże znaczenie w zakresie uregulowania ich praw w Polsce ma również Karta Praw Osób Niepełnosprawnych. Jednakże złożoność przepisów jest z pewnością znaczącym utrudnieniem w zatrudnieniu takich osób. Ponadto Ustawa o rehabilitacji zawodowej i społecznej oraz zatrudnianiu osób niepełnosprawnych była wielokrotnie nowelizowana, co też negatywnie wpływa na ich zatrudnianie. „Niestabilna sytuacja prawna tworzy ryzyko zmian w kwestii odpowiedzialności pracodawców. Narzuca to dodatkowe koszty spowodowane koniecznością bieżącego zaznajamiania się z kształtem aktualnych przepisów, co może być znaczące, szczególnie dla mniejszych firm, które nie posiadają wysoko wyspecjalizowanego działu kadr" (Chłoń-Domińczak 2007, s. 17). Pracodawca może obawiać się konsekwencji, np. niezastosowania się do przepisu, który uległ zmianie. Jeśli dołączymy do tego barierę obyczajową, to widzimy wyraźnie, że prowadzona na tym polu polityka społeczna jest skazana na niepowodzenie. Organem wspierającym działania na rzecz aktywizacji omawianej grupy na rynku pracy jest Państwowy Fundusz Rehabilitacji Osób Niepełnosprawnych (fundusz celowy, istniejący przy Ministerstwie Pracy i Polityki Społecznej). Należy zastanowić się, czy działania PFRON są adekwatne do potrzeb i czy są aktualizowane zgodnie ze zmieniającymi się trendami w zatrudnieniu.

Czynnikiem negatywnie wpływającym na wskaźnik zatrudnienia może być także finansowanie pracodawców, którzy chcą zatrudnić niepełnosprawnego pracownika. Pracodawca ma prawo wnioskować o refundację stanowiska pracy i o częściową refundację pensji takiej osoby (jej wysokość jest uzależniona od stopnia niepełnosprawności). Tak udzielane wsparcie może przyczynić się do nadużyć polegających np. na wykorzystaniu pieniędzy PFRON na remont budynku czy wybudowanie windy $z$ racji zatrudnienia pracownika niesprawnego ruchowo, pracownik jest wtedy środkiem do osiągnięcia celu: podwyższenia standardu budynku za pieniądze przeznaczone na wspieranie niepełnosprawnych. Natomiast refundacja pensji pracownika może prowadzić do zaburzeń na gruncie świadomego zatrudniania - w efekcie możliwość pracy dla niepełnosprawnych staje się luksusem, którego koszty ponosi w pewnym stopniu państwo, a nie standardem i takim samym prawem do pracy, jakie posiada osoba pełnosprawna, zgodnie z ideą stwarzania równych szans. Oczywiście koniecznością jest dostosowywanie miejsc pracy, ale należy również zwrócić uwagę na fakt, że obawy przed występowaniem nadużyć mogą być uzasadnione. Warto zaakcentować też, że pracodawca, który nie osiąga wymaganego wskaźnika zatrudnienia, musi płacić PFRON kary. Prowadzenie takiej polityki społecznej nie buduje długofalowego zaufania między pracodawcą a pracownikiem, jeśli bowiem motywacją do zatrudnienia osoby z niepełnosprawnością jest rekompensata ze strony państwa, to przestają liczyć się umiejętności pracownika i równe prawa. System dofinansowań w Polsce wymaga 
zdecydowanych zmian. Ważne jest również podnoszenie świadomości społecznej w tym zakresie.

\section{Czym jest zatrudnienie wspomagane?}

Zatrudnienie wspomagane jest formą aktywnego i szerokiego wsparcia w znalezieniu i utrzymaniu zatrudnienia na otwartym rynku pracy. Odbiorcami takich działań są głównie osoby ze stwierdzoną niepełnosprawnością, które z różnych względów nie są w stanie same poradzić sobie w tej sferze życia. Orzeczenie o niepełnosprawności jest o tyle istotne, że - jak już było wspomniane - daje potencjalnemu pracodawcy możliwość skorzystania z różnego rodzaju korzyści. Ponadto pracodawca zatrudniający osoby niepełnosprawne kształtuje pozytywny wizerunek swojej firmy. Model zatrudnienia wspomaganego jest więc korzystny nie tylko dla osób, którym udziela się wsparcia (beneficjentów tego rodzaju działań), ale również dla drugiej strony, którą tworzą przedsiębiorcy.

Od lat funkcjonuje on w wielu krajach Unii Europejskiej i w USA, a jego efektywność ocenić można po liczbie pracujących niepełnosprawnych - średnia dla krajów UE to ponad $50 \%$. Należy jednak pamiętać, że model zatrudnienia wspomaganego powstał w krajach o wysokim dochodzie, w których świadczenia formalne są dobrze ugruntowane. Natomiast w krajach o niskim dochodzie, a szczególnie w regionach wiejskich i słabo rozwiniętych, głównym źródłem zatrudnienia jest praca w tzw. szarej strefie. Osoby z niepełnosprawnością intelektualną wykonują często zajęcia typowe dla obszarów wiejskich, np. w gospodarstwach rolnych. Podobny wzór zatrudnienia był charakterystyczny w krajach zachodnich przed uprzemysłowieniem (Parmenter 2011). W Polsce w dalszym ciągu liczba niepełnosprawnych aktywnych zawodowo jest stosunkowo niska (oscyluje w granicach około $20 \%$ ). Niestety, z uwagi na brak rozwiązań systemowych zatrudnienie wspomagane jest wciąż bardzo mało popularną formą aktywizacji zawodowej. W naszym kraju projekty oparte na modelu zatrudnienia wspomaganego realizowane są głównie przez organizacje pozarządowe, które bazują na środkach pochodzących z Polskiego Funduszu Rehabilitacji Osób Niepełnosprawnych i programów Unii Europejskiej, ich zakres jest jednak ograniczony ze względu na niedostateczną ilość tych środków.

Podstawą modelu zatrudnienia wspomaganego jest udzielanie beneficjentowi szerokiego wsparcia przez osobę specjalnie do tego przygotowaną - trenera pracy. Jest on specjalistą przynajmniej w dwóch aspektach - pierwszy dotyczy wiedzy z zakresu prawa pracy i doradztwa zawodowego, a drugi odnosi się do umiejętności interpersonalnych, szczególnie w kontakcie z osobami mającymi specjalne potrzeby. Połączenie aktywizacji zawodowej ze społeczną przynosi najlepsze i najbardziej trwałe rezultaty. Działania trenera pracy są skierowane do osób z różnym rodzajem i stopniem niepełnosprawności, ich celem jest usamodzielnienie tych, którzy chcą podjąć i utrzymać zatrudnienie na otwartym rynku pracy. Realizacja takiego założenia wymaga holistycznego podejścia do beneficjenta, dopasowanego 
do jego umiejętności, kompetencji społecznych, wykształcenia oraz stanu zdrowia. Należy pamiętać, że każdy rodzaj niepełnosprawności ma swoją specyfikę - szczególne objawy i ograniczenia, dlatego tak ważne jest indywidualne podążanie za osobą niepełnosprawną w realizacji poszczególnych celów.

Zatrudnienie wspomagane jest też nazywane modelem rehabilitacji zawodowej. Można to określić w następujący sposób: umieścić w miejscu pracy - wyszkolić - utrzymać w miejscu pracy. Taki schemat uznaje potrzebę szukania osobom niepełnosprawnym zwyczajnych miejsc pracy, ale możliwie zróżnicowanej. Ta różnorodność i wymagania związane z konkretnym miejscem pracy są trudne do odwzorowania w warunkach szkoleniowych czy pracy chronionej. Osoba objęta kompleksowym programem zatrudnienia wspomaganego jest przygotowana do wykonywania specyficznego zawodu (Hamond, Haccou 2007).

W oparciu o własne doświadczenia zawodowe mogę stwierdzić, że bardzo ważnym elementem procesu zatrudnienia wspomaganego jest tzw. profil zawodowy osoby niepełnosprawnej. Są to zebrane i szczegółowo opisane wiadomości o niej i jej potencjale zawodowym. Do każdego beneficjenta należy podchodzić indywidualnie, biorąc pod uwagę wiele zmiennych, takich jak: dotychczasowe doświadczenie zawodowe, umiejętności społeczne czy motywację do podjęcia zatrudnienia. Oprócz pomocy w opracowaniu dokumentów aplikacyjnych i znalezieniu ofert pracy wskazane jest również wsparcie psychologiczne. Idealnym rozwiązaniem jest zapewnienie wsparcia indywidualnego oraz grupowego (umożliwiającego trening funkcjonowania w grupie). Oswojenie z problematyką, możliwość podzielenia się swoimi odczuciami i obawami oraz poczucie bycia kimś ważnym, zauważonym pozwalają z większą swobodą wkraczać w nieznane środowisko pracownicze.

W swojej praktyce zawodowej często obserwuję, że aktywizacja zawodowa jest niekiedy poprzedzona „pracą u podstaw”. Składają się na nią: treningi higieny osobistej, poruszania się po mieście, zachowania w miejscu publicznym i w kontakcie z pracodawcą. Bardzo ważnym elementem założeń zatrudnienia wspomaganego jest relacja $\mathrm{z}$ pracodawcą, w której trener pracy często odgrywa rolę pomostu między zatrudnianym a zatrudniającym. Dzięki niemu pracodawcy mają okazję poznać specyfikę medyczną choroby czy niepełnosprawności, z którą zgłasza się kandydat na pracownika, strategie radzenia sobie i udzielania pomocy w sytuacjach pojawienia się objawów choroby czy pokonywania ograniczeń wynikających z danej niepełnosprawności, a także metody komunikacji. Pracodawcy są zachęcani do większej otwartości i poznania indywidualnie kandydata bez etykietowania danej ułomności. Należy pamiętać, że każda niepełnosprawność charakteryzuje się innym natężeniem, a także specyfiką objawów. Zdecydowanie należy unikać generalizacji medycznej.

W trudnych sytuacjach, konfliktowych lub budzących zaniepokojenie, trener pracy staje się również negocjatorem. Takie stałe pośredniczenie pomiędzy beneficjentem a pracodawcą jest kolejnym etapem działań zatrudnienia wspomaganego. Trener pracy przekazuje też informacje z zakresu prawa pracy - głównie dotyczące 
ulg i możliwości dofinansowania wynagrodzeń dla osób z aktualnym orzeczeniem o niepełnosprawności. Należy również zapoznać się z przyszłymi współpracownikami beneficjenta. Takie spotkanie jest wcześniej omawiane zarówno z nim, jak i z jego przełożonym. Celem tego działania jest pomoc w zaaklimatyzowaniu się w nowym środowisku. Duży nacisk kładzie się na psychoedukację współpracowników, co ma na celu zmniejszenie lęku, uprzedzeń, poszerzenie wiedzy o poszczególnych rodzajach niepełnosprawności czy też formach komunikacji. Trener pracy jest dla beneficjenta oraz pracodawcy i to oni decydują, na ile jest im potrzebne jego wsparcie.

Pracując jako trener pracy, wielokrotnie miałam okazję obserwować, że uczestnictwo $\mathrm{w}$ projekcie zatrudnienia wspomaganego, a później podjęte zatrudnienie, w pozytywny sposób wpływają na życie beneficjentów. Osoby, które zgłaszają się do projektów oferujących zatrudnienie wspomagane, nie zawsze są od razu gotowe do podjęcia nowych wyzwań. Stopniowe przyzwyczajanie do myśli o wyjściu $\mathrm{z}$ domu, otwarciu na świat, który z założenia niesie różnego rodzaju zagrożenia, to jedyna metoda zmiany tych przekonań. Podobnie jest $\mathrm{z}$ rodzinami beneficjentów. Zwłaszcza rodzice nie zdają sobie sprawy, jak bardzo terapeutyczną funkcję spełnia praca, jak jest potrzebna dla uzyskania pozytywnych efektów rehabilitacji ich dzieci. Poza tym wzrost samodzielności bywa dla rodziców powodem stresu i lęku, bo dotychczasowe ułożone życie wywraca się „do góry nogami”. Spotkania prowadzone z bliskimi mają na celu oswojenie ich z myślą o dzieciach jako autonomicznych jednostkach, które są w stanie funkcjonować bez ich stałej opieki. Często problemem nie jest samo znalezienie pracy, ale jej utrzymanie. W tym procesie ważne są reakcje otoczenia - współpracowników oraz rodziny, najbliższych. Silne konflikty na którejkolwiek linii osłabiają poczucie sprawstwa i pogarszają funkcjonowanie beneficjentów. Te wszystkie potrzeby grupy docelowej, jaką są osoby niepełnosprawne, podnoszą znaczenie zawodu trenera pracy. Jego rola w relacji z klientem zmienia się z biegiem czasu i nabywania nowych kompetencji społecznych oraz zawodowych. Początkowo jest on przewodnikiem, mentorem. Pokazuje, co i jak można zrobić, pomaga w wykonywaniu różnych czynności, towarzyszy w pokonywaniu lęku, który pojawia się na ogół w nowej sytuacji. W momencie, kiedy osoba z niepełnosprawnością jest gotowa na sprawdzenie własnych możliwości i umiejętności, trener pracy staje się towarzyszem. Pojawia się w momencie, kiedy potrzebuje go beneficjent, jego pracodawca czy członek rodziny. Trener pracy pomaga osobom z niepełnosprawnością w dążeniu do autonomii, będącej podstawową wartością życia każdego człowieka. Beneficjenci potrzebują więcej czasu aniżeli osoby zdrowe, ale mają takie same prawa i powinni mieć takie same szanse na rozwój. Trener pracy musi posiadać wszechstronną wiedzę i łatwość komunikacji z różnymi grupami społecznymi.

Niewątpliwie zawód ten powinien być jak najszerzej rozpowszechniany. Daje osobom go wykonującym ogromną satysfakcję, przynosi konkretne rezultaty oraz zapewnia możliwość samorealizacji. Zatrudnienie wspomagane jest specjalistycznym, 
kompleksowym instrumentem wspierania na rynku pracy aktywności tych osób, u których rodzaje i nasilenie niepełnosprawności powodują, że ich sytuacja na tym rynku jest szczególnie trudna. Zastosowanie takiej formy wsparcia pozwala im na podjęcie pracy i utrzymanie zatrudnienia w przyszłości. Praca wspomagana uznana została w wielu krajach na świecie za najbardziej efektywną formę zatrudnienia.

System wspomaganego zatrudnienia, jak wspomniano na początku, rozwinął się w Stanach Zjednoczonych w związku z promocją zasady zawodowej integracji osób niepełnosprawnych. Według tej zasady osoby niepełnosprawne powinny być w pierwszej kolejności zatrudniane na otwartym rynku pracy. W 1970 roku amerykański terapeuta Mark Gold opracował behawioralną strategię nauczania: kształcenie systematyczne $=$ nauka $\mathrm{w}$ sytuacjach prawdziwych $=$ koncepcja job coachingu. Ta metoda została stworzona dla ludzi uznawanych za niezdolnych do „prawdziwej” pracy. Systematyczne szkolenia i wsparcie, jakie otrzymywali w rzeczywistych miejscach pracy, sprawiły, że rozwijali i poszerzali swoje umiejętności, a w rezultacie podejmowali „normalną” pracę. Koncepcja job coachingu jest oparta na zmianie podejścia do usług w zakresie aktywizacji zawodowej osób niepełnosprawnych na otwartym rynku pracy poprzez zmianę myślenia $\mathrm{z}$ „przeszkolić - zatrudnić” na „zatrudnić - wyszkolić - utrzymać”. W latach siedemdziesiątych i osiemdziesiątych model zatrudnienia wspomaganego wprowadziło wiele krajów na świecie, np. Australia, Kanada, Hongkong, Nowa Zelandia, Peru czy Zambia. Równocześnie w wielu państwach Europy Zachodniej powstały krajowe stowarzyszenia zatrudnienia wspomaganego, np. w Czechach, na Słowacji. W Polsce zatrudnienie wspierane funkcjonuje od 2002 roku. Za ważny powód jego zainicjowania można uznać krytykę zakładów pracy chronionej - uznanych za „obozy”, które nie dają możliwości rozwoju zawodowego, a generują duże koszty. Analizując niskie wskaźniki zatrudnienia osób niepełnosprawnych na otwartym rynku pracy, stwierdzono, że ich przyczyny leżą zarówno po stronie niepełnosprawnych, jak i pracodawców. Osoby niepełnosprawne mają trudności w adaptacji, zwłaszcza w początkowym okresie zatrudnienia. Dotyczą one wykonywania zadań zawodowych zgodnie z oczekiwaniami pracodawców i powodowane są niedostatecznym przygotowaniem ogólnym i zawodowym oraz brakiem przystosowania do fizycznego i społecznego środowiska pracy. W związku z tym osoby te potrzebują odpowiedniej pomocy i wspomagania.

Efektywne zatrudnienie wspomagane wymaga stworzenia kompleksowego modelu aktywizacji zawodowej, wypracowania standardów wdrażania i formalno-prawnych aspektów funkcjonowania. Jego założenia powinny opierać się na indywidualnym podejściu do osoby niepełnosprawnej. Dzięki temu można określić możliwości i zminimalizować ograniczenia. Założenia zatrudnienia wspomaganego są zgodne z Konwencją Praw Osób Niepełnosprawnych, która podkreśla poszanowanie godności osobistej, autonomii i swobody wyboru. Kompleksowość modelu polega także na włączaniu osoby niepełnosprawnej i jej bliskiego otoczenia $\mathrm{w}$ aktywny proces poszukiwania pracy. Ta forma wsparcia ciągle nie jest jeszcze 
w Polsce usankcjonowana prawnie. Nie ma też precyzyjnego wskazania, kogo konkretnie ma dotyczyć. Przyjmuje się, że odnosi się do osób, którym ze względu na rodzaj i stopień uszkodzenia organizmu najtrudniej jest poszukiwać zatrudnienia na otwartym rynku pracy. Zatrudnienie wspomagane jest więc w Polsce realizowane przez organizacje pozarządowe działające na rzecz niepełnosprawnych w bardzo zróżnicowanych formach i na bardzo różnych zasadach, w stosunku do osób z wieloma rodzajami niepełnosprawności, w tym przede wszystkim $z$ niepełnosprawnością intelektualną i chorobami psychicznymi, ale także dotkniętych niepełnosprawnościami sprzężonymi.

Schemat 1. Model zatrudnienia wspomaganego.

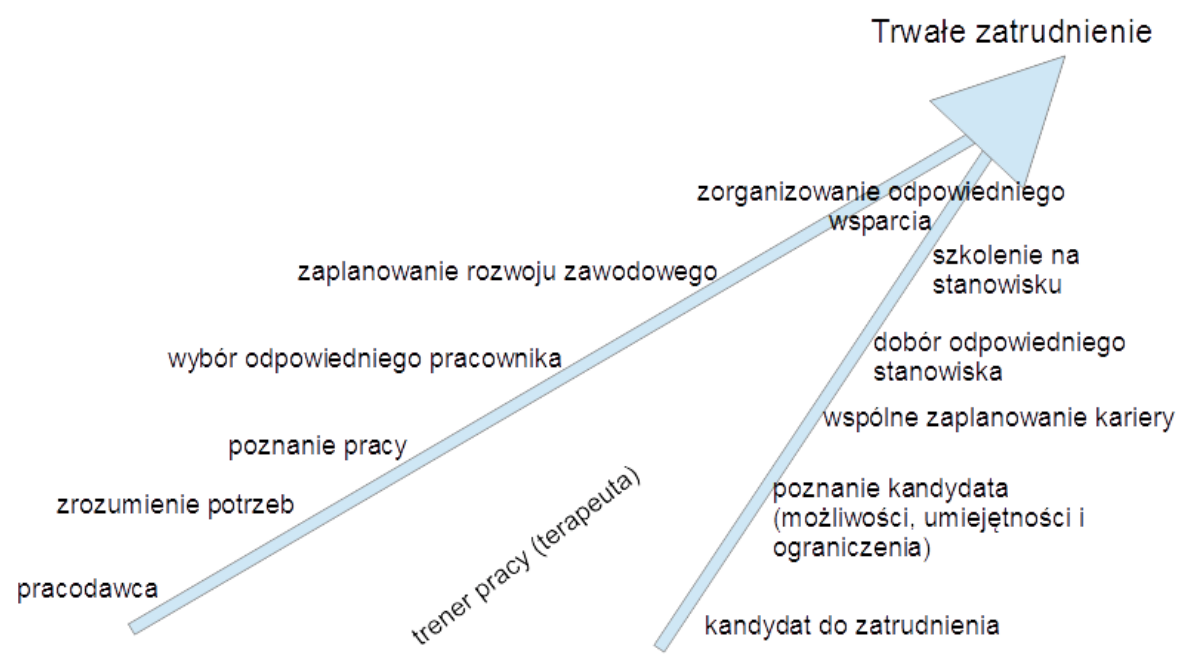

źródło: opracowanie własne na podstawie Scottish Union for Supported Employment (http://www. susescotland.co.uk/)

\section{Rola trenera pracy}

Warto jeszcze raz zaakcentować fakt, że znalezienie pracy jest równie trudne, jak jej utrzymanie. W niektórych przypadkach to drugie jest nawet trudniejsze. W tej kwestii bardzo ważną rolę odgrywa trener pracy, jego właściwe podejście oraz upór i wiara w możliwości beneficjenta. Trener pracy jest niewątpliwie istotnym ogniwem pracy wspomaganej. Jeszcze raz szczegółowo sprecyzuję jego zadania.

$Z$ reguły trener pracy najpierw szkoli się sam, pracując na danym stanowisku, potem wprowadza osobę niepełnosprawną, towarzyszy jej przez cały okres adaptacji w miejscu pracy, odpowiada za wyszkolenie do pełnienia obowiązków i pomoc 
w ułożeniu relacji ze współpracownikami. Działania, jakie podejmuje trener pracy, mają na celu wspieranie trwałej zmiany w kierunku osobistego rozwoju osoby niepełnosprawnej w roli pracownika. Funkcję trenera pracy można zatem porównać do pomostu między osobami niepełnosprawnymi i pracodawcą oraz współpracownikami. Do zadań trenera pracy należą również pomoc w przygotowywaniu dokumentów aplikacyjnych, wyszukiwanie ofert pracy zgodne z preferencjami i możliwościami beneficjentów, rozpoznawanie środowiska pracy u konkretnego pracodawcy, zadań, jakie będzie wykonywał beneficjent, stałe monitorowanie przebiegu pracy i, w razie potrzeby, prowadzenie szkoleń uzupełniających oraz motywowanie. Ponadto trener pracy współpracuje z psychologiem i doradcą zawodowym, negocjuje z pracodawcą odpowiednie warunki zatrudnienia, zapewnia pomoc organizacyjną w zakresie związanym z wykonywaną pracą, szkoli personel, aby umiał współpracować i komunikować się z niepełnosprawnym pracownikiem, przeprowadza trening poruszania się po mieście, udzielając pomocy w dojazdach do i z miejsca pracy.

Dzięki wsparciu trenera pracy niepełnosprawny pracownik może stać się wykwalifikowanym specjalistą w zakresie czynności zawodowych, których się podejmuje. Obecność wyszkolonego trenera pracy powoduje, że nie obciąża on załogi koniecznością troszczenia się o niego, pomagania mu i wprowadzania w nowe obowiązki. Trenerzy z reguły posiadają wykształcenie wyższe pedagogiczne lub/i psychologiczne oraz doświadczenie w pracy z osobami niepełnosprawnymi. Są to zazwyczaj osoby, które potrafią odnaleźć się na różnych samodzielnych stanowiskach pracy. Wkładają dużo starań i cierpliwości, aby niepełnosprawni pokonywali swoje słabości i lęki. Ważne jest zaszczepienie niepełnosprawnej osobie świadomości, że każda praca wnosi w życie poczucie obowiązku, odpowiedzialności, wymaga samodyscypliny, samozaparcia, przyzwyczaja do poprawnych zachowań w społeczeństwie. Niezbędna jest również świadomość, że dobrze wykonana praca poza wynagrodzeniem daje poczucie satysfakcji, możliwość rozwijania się, wpływa na optymistyczne postrzeganie świata, pomaga też $\mathrm{w}$ radzeniu sobie $\mathrm{z}$ różnymi trudnymi sytuacjami. Trener pracy konsekwentnie wspiera beneficjenta, wierzy w szansę powodzenia swojego treningu. Prawdopodobnie gdyby nie on, wiele osób niepełnosprawnych zrezygnowałoby z pracy z niską samooceną i być może straciłoby szansę na samodzielną egzystencję w przyszłości.

Trenerzy pracy, poza różnymi trywialnymi problemami, spotykają się też z trudnymi i nieprzyjemnymi sytuacjami wynikającymi z ignorancji i braku woli zrozumienia istoty zatrudnienia wspomaganego. Są to jednak przypadki jednostkowe. Trener pracuje równolegle $\mathrm{z}$ beneficjentem od początku jego zatrudnienia. Jednak z każdym dniem sukcesywnie wycofuje się ze swojej ingerencji, w razie potrzeby dyskretnie udzielając wskazówek i wsparcia aż do uzyskania samodzielności. Bardzo istotna jest świadomość, że trener pracy nie jest dodatkową osobą do wykonywania konkretnej pracy, jak często myślą pracodawcy. Warto zawsze zaznaczyć ten fakt na początku kontaktu. 


\section{Dobre praktyki organizacji pozarządowych}

W celu zgłębienia specyfiki zatrudnienia wspomaganego osób niepełnosprawnych warto zaprezentować dobre praktyki i doświadczenia z projektów realizowanych przez dwie przykładowe organizacje pozarządowe: Towarzystwo Pomocy Głuchoniewidomym oraz Fundację Pomocy Młodzieży i Dzieciom Niepełnosprawnym „Hej, Koniku!”.

Początek zatrudnienia wspomaganego w TPG to 2000 rok. Wówczas do organizacji przyjechali przedstawiciele Fundacji Hiltona/Perkinsa, którzy mieli duże doświadczenie $\mathrm{w}$ pracy $\mathrm{z}$ osobami $\mathrm{z}$ jednoczesnym uszkodzeniem narządu wzroku i słuchu. Jednym z tematów, jaki poruszono podczas spotkania, była właśnie aktywizacja zawodowa osób głuchoniewidomych. Dzięki temu w TPG pojawił się projekt pilotażowy „Rehabilitacja zawodowa młodych osób głuchoniewidomych". W projekcie tym na stanowisku asystenta zawodowego została zatrudniona Krystyna Klugiewicz (odpowiednik trenera pracy). Osobami poszukującymi pracy byli absolwenci szkoły dla osób głuchoniewidomych w Bydgoszczy. W ramach projektu wsparciem zostały objęte cztery osoby. W rezultacie dwie z nich znalazły zatrudnienie w placówce przedszkolnej przy pracach porządkowych oraz kuchennych, trzecia osoba rozpoczęła pracę $\mathrm{w}$ zakładzie pracy chronionej zajmującym się produkcją lamp samochodowych, a czwarta - w Instytucie Głuchoniemych $\mathrm{w}$ charakterze pomocy nauczyciela. Trener pracy wykonywała takie zadania jak: pomoc w poszukiwaniu pracy, wsparcie na stanowisku pracy oraz monitoring po podjęciu zatrudnienia. Zdarzały się sytuacje, które wymagały interwencji w miejscu zamieszkania beneficjenta. Wówczas trener pracy jechała do konkretnej osoby i spędzała u niej tydzień lub dwa, aby mieć pewność, że wszystkie czynności wchodzące w zakres obowiązków zostały już opanowane, i by ją motywować. Utrzymywała stały kontakt $\mathrm{z}$ rodzinami. Warto zwrócić uwagę na mobilność trenerki (wspierała osoby mieszkające w różnych częściach Polski). W 2008 roku powstał projekt pilotażowy pt. „Wsparcie osób głuchoniewidomych na rynku pracy”, realizowany w partnerstwie z PFRON. Był to pierwszy w Polsce plan aktywizowania tej grupy osób na tak ogromną skalę z wykorzystaniem znaczących funduszy. W projekcie wzięło udział 400 głuchoniewidomych z całej Polski. Była to ogromna liczba $\mathrm{z}$ uwagi na fakt, że w Polsce takich osób jest ok. 800o. Trenerów pracy było tylko czterech, jak się później okazało - stanowczo za mało. Stąd też ich funkcję bardzo często pełnili doradcy zawodowi. Ich rola, tak jak w przypadku Krystyny Klugiewicz, polegała na udzielaniu wsparcia przed uzyskaniem zatrudnienia lub stażu, $\mathrm{w}$ trakcie i po nim. Dodatkowym bardzo ważnym elementem była praca $\mathrm{z}$ rodziną. $\mathrm{W}$ miarę czasu i możliwości nawiązywano kontakty z pracodawcami, publicznymi i niepublicznymi instytucjami rynku pracy. Projekt pilotażowy zakończył się w styczniu 2010 roku. Bilans wyglądał tak, że zamiast planowanych pięciu ostatecznie zatrudniono aż 25 osób. To niewątpliwie duży sukces. Nie warto jednak rozbudzać zawodowych aspiracji tych osób, a potem zostawiać ich samym sobie. 
Praca $\mathrm{z}$ osobą głuchoniewidomą to $\mathrm{w}$ wielu przypadkach długi, często wieloletni proces, wymagający wiele trudu.

Wnioski z poprzednich projektów zostały uwzględnione w projekcie pt. „Wsparcie osób głuchoniewidomych na rynku pracy II - weź sprawy w swoje ręce”, realizowanym w latach 2010-2013. Jak się jednak okazało, tylko część beneficjentów tak naprawdę nosiła się z zamiarem podjęcia pracy. Dla wielu osób w poprzednim projekcie celem było uzyskiwanie konkretnego rodzaju wsparcia (szkolenia, wsparcia psychologa). Używając terminologii z projektu, była to duża wartość dodana - pierwszy raz osoby niepełnosprawne z tej organizacji uzyskały tak ogromne wsparcie. Kolejnym doświadczeniem było to, że mimo wszystko projekt dawał dużo większe szanse na pracę bardziej zrehabilitowanym. Osoby, które bardzo słabo funkcjonowały, nie miały możliwości uzyskania kompleksowej i długofalowej pomocy. Wsparcie trenera - przyznane w postaci określonej liczby godzin - było zbyt małe, aby umożliwić im wejście na rynek pracy i utrzymanie się na nim. Ci, którzy dostali niewiele i im to wystarczyło, odnosili sukcesy zawodowe i nie tylko. Pozostała grupa - chętnych, ale wymagających większej pomocy - nadal nie uzyskała pracy czy stażu. Stąd też ogromna potrzeba wsparcia ze strony trenera pracy, który będzie w stanie zapewnić długofalową i ciągłą pomoc. Z uwagi na zasięg działania i możliwości finansowe zatrudniono dziesięcioosobową grupę trenerów pracy. Na podstawie analiz z poprzedniego projektu oszacowano, ile osób i z jakich miast będzie chętnych podjąć pracę lub staż. Z bazy zebranych danych wybrano dziesięć miast w Polsce, gdzie umieszczono trenerów pracy. Wybrane osoby przeszły długie szkolenie. Od połowy sierpnia do końca września 2010 roku udało się zatrudnić sześć osób głuchoniewidomych, a jednej osobie znaleźć staż. Trenerzy pracy, rozpoczynając proces wspierania w zatrudnieniu osoby głuchoniewidomej, musieli być gotowi na złożoność tej niepełnosprawności oraz trudności z tym związane. W przypadku pracy z osobami głuchoniewidomymi niezbędna jest zarówno znajomość języka migowego i alfabetu Lorma czy specyfiki osób głuchych, jak też znajomość technik poruszania się i wiedza z zakresu tyflopedagogiki. Jednoczesne uszkodzenie narządu wzroku i słuchu powoduje brak lub ograniczenie kompensacji, przez co praca z osobą głuchoniewidomą staje się dużym wyzwaniem (Zaorska 2002). Można powiedzieć, że złożoność tej niepełnosprawności powoduje, iż trener musi mieć kompleksową wiedzę i umiejętności, by pracować z różnymi typami osób głuchoniewidomych, a w dodatku kompetencje z czterech różnych obszarów: doradztwa zawodowego, pozyskiwania pracodawców, zatrudnienia wspomaganego oraz głuchoślepoty. Trenerzy pracy okazali się znakomitymi realizatorami projektu. Wprowadzenie ich przyczyniło się do znalezienia pracy dla 130 beneficjentów.

W Fundacji Pomocy Młodzieży i Dzieciom Niepełnosprawnym „Hej, Koniku!” projekty, których celem jest zatrudnienie wspomagane, są realizowane już od 2007 roku. W kolejnych edycjach wsparcie uzyskało prawie 200 osób z różnymi niepełnosprawnościami. Wskaźnik osób zatrudnionych w wymienionych projektach wynosi około 45\%. Grupę, na której głównie skupiają się działania fundacji „Hej, 
Koniku!", stanowią osoby z postawioną diagnozą psychiatryczną. Pomysł, aby to ich objać wsparciem, zrodził się w fundacji w trakcie procesu rekrutacji do nowego projektu. Zauważono, że większość kandydatów posiada orzeczenie z symbolem o2-P (zaburzenia psychiczne). Były to osoby najbardziej zmotywowane do zmiany swojego życia i podjęcia zatrudnienia. Jednocześnie istniała potrzeba wzmożonej pracy nad ich umiejętnościami interpersonalnymi. Kolejnym krokiem było uruchomienie treningów grupowych i powstanie swoistej grupy wsparcia, której członkowie wymienialiby się doświadczeniami oraz przemyśleniami nie tylko na temat aktywizacji zawodowej, ale też życiowych problemów, i zaczęli postrzegać siebie jako jednostki będące w nieustannej interakcji z otoczeniem, dbające zarówno o potrzeby własne, jak i innych ludzi.

Od kwietnia tego roku rozpoczęła się kolejna edycja projektu „Zatrudnienie wspomagane”. Realizowany jest on wspólnie z Fundacją Eudajmonia z Wrocławia. W pierwszym roku planowane jest objęcie aktywizacją społeczno-zawodową 120 osób z województw warmińsko-mazurskiego, dolnośląskiego i mazowieckiego. Projekt realizowany będzie w dwóch edycjach: od 1 kwietnia 2015 do 30 marca 2016 roku i od 1 kwietnia 2016 do 31 marca 2017 roku. Dodatkowo osoby z niepełnosprawnością będą mogły skorzystać ze wsparcia asystenta funkcjonalnego, np. osoby z niepełnosprawnością ruchową, osoby niewidome z pomocy przewodnika, a osoby niesłyszące ze wsparcia tłumacza języka migowego. Projekt realizowany jest zgodnie ze standardami Europejskiej Unii Zatrudnienia Wspomaganego, z wykorzystaniem dotychczasowych doświadczeń partnerów.

\section{Podsumowanie}

W kwestii zatrudniania osób niepełnosprawnych na otwartym rynku pracy jest jeszcze dużo do zrobienia. Zatrudnienie wspomagane daje szansę wielu osobom niepełnosprawnym na bycie pełnowartościowymi członkami społeczeństwa. Zawsze znajdzie się ktoś, kto powie, że taka osoba nie może pracować. Takie stwierdzenie wysuwa pracownik administracyjny w urzędzie, przedsiębiorca czy też lekarz medycyny pracy. Głuchy nie może, niewidomy nie może, osoba poruszająca się na wózku inwalidzkim nie może, a osoba ze sprzężoną niepełnosprawnością to już z pewnością nie może. Trzeba poświęcić wiele czasu i włożyć wiele wysiłku, by obalić stereotypy dotyczące osób niepełnosprawnych na otwartym rynku pracy, szczególnie ze sprzężonymi niepełnosprawnościami. To ważne zadanie dla organizacji pozarządowych i pole do działania dla trenerów pracy. Zdecydowanie należy podnieść rangę tego zawodu. Trenerami pracy powinny być osoby kompetentne i gruntownie przygotowane do swoich zadań.

W polityce zatrudnienia należy kontynuować i rozszerzać wsparcie dla organizacji pozarządowych, które chcą tworzyć i tworzą stanowiska pracy dla osób niepełnosprawnych, a także prowadzą projekty aktywizacyjne. Wypracowane już w przytoczonych przykładach dobre praktyki w zatrudnianiu wspomaganym 
powinny być powielane w innych organizacjach i instytucjach. Należy też brać pod uwagę fakt, że pomimo wszelkich starań i wielokierunkowego wsparcia nie wszyscy niepełnosprawni są w stanie podjąć pracę na otwartym rynku pracy. Dlatego warto również wspierać spółdzielnie socjalne. Głównym wnioskiem wynikającym z powyższych rozważań jest konieczność zmian w polityce społecznej wobec osób niepełnosprawnych. Należy podjąć zdecydowane działania na rzecz w prowadzenia prawa antydyskryminacyjnego, uprościć procedury związane z zatrudnianiem niepełnosprawnych, znieść kary i ograniczenia co do liczby zatrudnianych pracowników z niepełnosprawnością, przeprowadzić rewizję systemu dofinansowań płac i stanowisk pracy. Państwo powinno znaleźć w budżecie środki na rzecz adekwatnego do potrzeb dofinansowania tego systemu.

\title{
Bibliografia
}

Barnes C., Mercer G. (20o8). Niepełnosprawność. Warszawa: Wydawnictwo Sic!

Chłoń-Domińczak A., Poznańska D. (2007). Promocja zatrudnienia osób niepetnosprawnych na otwartym rynku pracy. Proponowane działania w Polsce. Budapeszt: Międzynarodowa Organizacja Pracy.

Hamond B., Haccou R. (2007). Zdobywanie i ewaluacja kompetencji społecznych. Warszawa: Polskie Forum Osób Niepełnosprawnych.

Parmenter T. (2011). Promowanie możliwości szkolenia i zatrudniania osób z niepełnosprawnościa intelektualna - doświadczenia międzynarodowe. Warszawa: Polskie Forum Osób Niepełnosprawnych.

Ustawa z dnia 27 kwietnia 2006 r. o spółdzielniach socjalnych (Dz.U. 2006, nr 94, poz. 651).

Ustawa z dnia 27 sierpnia 1997 r. o rehabilitacji zawodowej i społecznej oraz zatrudnianiu osób niepełnosprawnych (Dz.U. 1997, nr 123, poz. 776).

Zaorska M. (2002). Głuchoniewidomi w Polsce, specjalna pomoc, edukacja i rehabilitacja. Olsztyn: Wydawnictwo Uniwersytetu Warmińsko-Mazurskiego.

\section{LABOUR MARKET ACTIVATION OF DISABLED IN A SUPPORTED EMPLOYMENT MODEL}

\begin{abstract}
Nowadays people with disabilities comprise a fairly large social group in Poland. One of the main problems of this group is to obtain employment. Obviously, such an inference do not reflect and describe a situation of all disabled persons, but I strongly believe that the motion of the flexible labour market, with a good and solid security provided, might have found a great throng of supporters among them. Addressing this topic, so to speak, is crucial, because economic conditions and status of people with disabilities, up to now, indicates poverty, which undoubtedly have a negative impact on this social group. As a result, it is absolutely necessary
\end{abstract}


to look for new solutions. Labour market activation programmes and the model of supported employment directed to disabled people are considered as the most effective ways to help people with different kinds of disabilities finding their place on the labour market and being satisfied with their occupation.

Key words: disability, supported employment, job coach, open labour market

Ewa Oleszczak - magister pedagogiki, absolwentka Wydziału Pedagogiki Uniwersytetu Kardynała Stefana Wyszyńskiego w Warszawie. Praktyk wspomagania osób niepełnosprawnych na otwartym rynku pracy. Od 2008 roku pracuje z osobami niepełnosprawnymi. Zainteresowania badawcze: niepełnosprawność, zatrudnienie wspomagane osób niepełnosprawnych. Adres e-mail: j_ewa@o2.pl. 